\title{
Correlation of the Severity of Carotid Artery Stenosis Identified by 64 Detected CT using "CC" Method with Color Doppler Ultrasound Findings
}

\section{Kesitli BT'de "CC" Yöntemiyle Tespit Edilen Karotid Arter Darlık Şiddetinin Doppler Ultrasonografi Bulguları ile Korelasyonu}

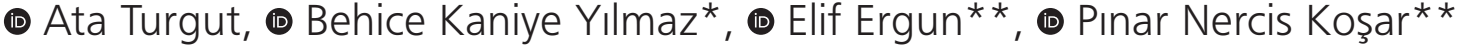 \\ Mardin Kızıltepe State Hospital, Clinic of Radiology, Mardin, Turkey \\ *Haseki Training and Research Hospital, Clinic of Radiology, istanbul, Turkey \\ **Ankara Training and Research Hospital, Clinic of Radiology, Ankara, Turkey
}

Abstract

Aim: The aim of this study was to investigate the correlation between the severity of carotid stenosis determined with 64-multidetector row computed tomographic angiography (CTA) (64-MDCTA) using the "common carotid" (CC) method and color Doppler ultrasound (CDUS) findings.

Methods: Two hundred and eighty-six internal carotid arteries (ICAs) of 143 patients with a history of transient ischemic attack/ stroke and suspected ICA stenosis who were referred for cervical CTA were examined. Plaque location, plaque type and stenosis severity were reported with CDUS and CTA. Stenosis severity was calculated with CTA using the CC method. The results were compared retrospectively.

Results: Plaques were observed in a total of 202 (72.2\%) ICAs by CDUS and using MDCTA in a total of 200 (71.4\%) ICAs. The plaques were classified according to the plaque type as soft, calcified and mixed by CDUS and by MDCTA Stenosis $\geq 70 \%$ was observed in $12.2 \%$ of cases on CDUS and in $10.0 \%$ of cases on CTA. A correlation of $91 \%(r=91, p<0.001)$ was observed between findings of CDUS and CTA for the determination of the grade of carotid stenosis.

Conclusion: Stenosis measurement done using the CC method is highly correlated with CDUS findings. The CC method is a candidate for widespread use in carotid stenosis measurement in routine practice.

Keywords: Carotid artery, stenosis, Doppler, plaque
Amaç: Bu çalışmanın amacı 64 kesitli multidedektör bilgisayarlı tomografi anjiyografide (BTA) "common carotid" (CC) yöntemine göre tespit edilen karotis darlık şiddetinin, renkli Doppler US (RDUS) bulguları ile korelasyonunu araştırmaktır.

Yöntemler: Geçici iskemik atak/inme öyküsü ve karotid arterlerde darlık şüphesi nedeniyle ile boyun BTA'ya refere edilen 143 hastada 286 internal karotid arter (ICA) incelendi. Plak lokalizasyonu, plak tipi ve stenoz derecesi RDUS ve BTA ile rapor edildi. Stenoz derecesi BTA'da CC metoduna göre hesaplandı. Elde edilen sonuçlar sırasıyla karşılaştıııldı.

Bulgular: RDUS'da toplam 202 iCA'da $(\% 72,2)$ ve BTA'da toplam 200 iCA'da $(\% 71,4)$ plak izlendi. İzlenen plaklar RDUS ve BTA ile yumuşak, kalsifik ve mikst plak olarak sınıflandırıldı. RDUS ile olguların $\% 12,2$ 'sinde $\geq \% 70$ 'inde darlık kaydedilirken, BTA'da olguların \%10,0'unda $\geq \% 70$ darlık kaydedildi. Karotid darlık düzeyi belirlenmesinde RDUS ve BTA bulguları arasında \%91 ( $r=91 p<0.001$ ) korelasyon tespit edilmiştir.

Sonuç: CC yöntemi ile yapılan stenoz ölçümlerin RDUS bulguları ile yüksek oranda koreledir. CC metodu karotid stenozunun ölçülmesinde rutin pratikte yaygın olarak kullanıma adaydır.

Anahtar Sözcükler: Karotid arter, stenoz, Doppler, plak
Address for Correspondence/Yazışma Adresi: Behice Kaniye Yılmaz, Haseki Training and Research Hospital, Clinic of Radiology, İstanbul, Turkey E-mail: behiceyilmaz@gmail.com ORCID: orcid.org/0000-0001-6842-3323 Received/Geliş Tarihi: 12 February 2019 Accepted/Kabul Tarihi: 18 April 2019
${ }^{\circ}$ Copyright 2019 by The Medical Bulletin of istanbul Haseki Training and Research Hospital The Medical Bulletin of Haseki published by Galenos Yayinevi. ๑Telif Hakkı 2019 istanbul Haseki Eğitim ve Araştırma Hastanesi Haseki Tıp Bülteni, Galenos Yayınevi tarafından yayınlanmıştır. 


\section{Introduction}

Carotid artery (CA) stenosis is regarded as one of the most important risk factors of transient ischemic attack and stroke which is the second most common cause of death in the world (1). In many studies, it has been demonstrated that the risk for stroke associated with extracranial CA diseases is related with the parameters such as grade of stenosis, plaque type and plaque characteristics (ulcerated, hemorrhagic plaque) (2). Grade of stenosis is considered the main parameter for selecting the most appropriate treatment and determining the grade of stenosis accurately is very important for the correct treatment approach (3).

Digital subtraction angiography (DSA) is considered the gold standard for the examination of the CAs and detection of stenosis. However, since the method is invasive and expensive, color Doppler ultrasound (CDUS) is usually used as the initial diagnostic method because it provides both anatomical and physiological information and is a cheap and reliable tool. However, CDUS has some disadvantages such as being operator-dependent, not displaying the vessel lumen in the presence of dense plaque calcification and spectral parameters may change according to the device brand. Hence, alternative modalities, such as magnetic resonance angiography (MRA) and computed tomographic angiography (CTA) have started to be used widely $(1,4,5)$.

Studies which used DSA as reference reported that CTA had a high sensitivity and specifity for determination of severe stenosis $(6,7)$.

The North American Symptomatic Carotid Endarterectomy Trial (NASCET), European Carotid Surgery Trial (ECST) and the common carotid (CC) methods are the three different methods used to measure the degree of internal CA (ICA) stenosis. Residual ICA luminal diameter at maximal lumen narrowing is compared with the normal distal ICA diameter in NASCET, with the estimated normal ICA diameter at the lesion level in ECST and with the normal CCA diameter in CC method. Using the three different methods in clinical practice can lead to confusion.

The aim of this study was to investigate the correlation between the severity of carotid stenosis determined with CTA using CC method and CDUS findings.

\section{Methods}

A total of 286 ICAs of 143 patients with a history of transient ischemic attack/stroke and suspected CA stenosis, who were referred for CTA examination between June 2009 and June 2010, were examined. Three patients were excluded due to short neck, high localized bifurcation and intensive plaque calcification. The remaining 140 patients (280 ICAs) were included in the study. Location of the plaque in the ICA and the plaque type were determined by CDUS and the grade of the stenosis was calculated. About 5-10 days after CDUS (mean 7 days), CTA was performed for all patients. Blinded to the results of CDUS, plaque location, plaque type and stenosis grade were reported. The stenosis grade in CTA was calculated using the CC method (8). The results were compared retrospectively, and correlation between the grade of carotid stenosis determined by 64-multidetector row CTA (64-MDCTA) and determined by CDUS was investigated.

CTA examinations were performed by a 64-slice computed tomography (CT) scanner (Aquilion, Toshiba, Tokyo, Japan). $75 \mathrm{~mL}$ (350 mg l/100 mL) non-ionic contrast medium was injected through a 20-gauge IV cannula placed in the right antecubital vein with a flow-rate of 5 $\mathrm{mL} / \mathrm{s}$ followed by $20 \mathrm{~mL}$ of saline. Optimal scan timing was determined manually and image acquisition was started as soon as the contrast medium arrived at the ICA at the level of cervical two vertebra. Slice thickness, field of view, pitch, mAs and kilovolt were $3 \mathrm{~mm}, 512 \times 512,320$ $\mathrm{mm}, 0.641,440$ and $120 \mathrm{kV}$, respectively.

The images obtained were transferred to a remote workstation for evaluation (Vitrea 2, Vital images Inc., Minnetonka, Minn., USA). Image analysis was done with the evaluation of axial images, multiplanar reconstruction (MPR) and oblique MPR images in the first line. Subsequently, the examination was detailed with maximum intensity projection (MIP), curved planar reformats $C P R$ and three-dimensional volume rendered (3D VR) reconstructions. 3D VR images were used for the anatomical evaluation rather than diagnostic purpose. Degree of carotid stenosis was assessed according to the CC method in which measurements were performed in oblique axial plane perpendicular to the lumen center line and the ratio of the diameter of the residual lumen at the site of maximal stenosis of the ICA bulbus to the diameter of normal common CA (CCA) lumen was calculated.

DUS examinations were performed with GE LOGIQ S6, with a $7.5 \mathrm{MHz}$ linear transducer. The patients were in the supine position with the head slightly extended and rotated opposite to the examined side. The grade of carotid stenosis was determined according to peak systolic velocity (PSV) and end diastolic velocity (EDV) at the site of maximal stenosis of the ICA bulbus and by calculating the ratio of ICA PSV-to-PSV in the CCA (9).

There is not necessary to obtain ethics committee approval nor informed consent, due to the study is retrospective.

\section{Statistical Analysis}

Continuous variables were expressed as arithmetic mean \pm standard deviation, and frequency of categorical variables were expressed as number. Consistency 
between severity of CA stenosis determined with DUS USG and MDCTA was analysed with correlation analysis and Pearson correlation (PC) test was done for this purpose. PC value varies between 0 and 1 and values above 0.9 indicates a strong correlation (correlation coefficient of $0.00-0.25$ is interpreted as a very weak correlation, 0.26-0.49 a weak correlation, 0.50-0.69 a moderate correlation, 0.70-0.89 a strong correlation, 0.90-1.0 a very strong correlation).

\section{Results}

Of the 140 patients included, 79 (56.4\%) were female, and $61(43.6 \%)$ were male. The mean age of the patients was 62.53 \pm 12.07 (range=28-91) years. In CDUS, plaques were observed in a total of 202 ICAs (72.2\%). Distribution and types of plaques detected by CTA and DUS are provided in Table 1 and 2 .

The degree of stenosis is evaluated in three groups: $<50 \%, 50-69 \%$, and $\geq 70 \%$. CDUS revealed an ICA stenosis of $<50 \%$ in 80 ICAs; $50-69 \%$ in 62 ICAs and $\geq 70 \%$ in 34 ICAs. CTA showed an ICA stenosis of $<50 \%$ in 88 ICAs; $50-69 \%$ in 56 ICAs and $\geq 70 \%$ in 28 ICAs (Figure 1a, 1b, 2a, 2b). In the determination of carotid stenosis, a correlation of $91 \%(r=91 p<0.001)$ was found between the findings of CDUS and CTA. The distribution of patients according to the grade of stenosis is shown in Table 3.

\section{Discussion}

Extracranial CA atherosclerosis is the major risk factor for cerebrovascular events. Parameters such as

\begin{tabular}{|c|c|c|}
\hline Plaque localization & CDUS (n, \%) & CTA $(n, \%)$ \\
\hline There was no plaque & $78(27.9 \%)$ & $80(28.6 \%)$ \\
\hline Right ICA & $116(41.4 \%)$ & $115(41.1 \%)$ \\
\hline Left ICA & $86(30.7 \%)$ & $85(30.3 \%)$ \\
\hline Total & 280 & 280 \\
\hline
\end{tabular}

\begin{tabular}{|c|c|c|}
\hline Plaque type & CDUS (n, \%) & CTA (n, \%) \\
\hline There was no plaque & $78(27.9 \%)$ & $80(28.6 \%)$ \\
\hline Soft plaque & $76(27.1 \%)$ & $78(27.9 \%)$ \\
\hline Calcified plaque & $18(6.4 \%)$ & $18(6.4 \%)$ \\
\hline Mixed plaque & $108(38.6 \%)$ & $104(37.1 \%)$ \\
\hline Total & 280 & 280 \\
\hline
\end{tabular}

CA stenosis, plaque type, ulcerations, and hemorrhage in the plaque are well-known factors associated with stroke (10). It has been demonstrated by the NASCET and ECST studies, which were conducted in the 1990s, and the Asymptomatic CA Stenosis Study conducted in 1995 that carotid endarterectomy was effective in preventing stroke in the presence of high-grade carotid stenosis. Therefore, accurate determination of stenosis grade is the most decisive point in determining the correct treatment approach (3).

DSA still remains the gold standard in the evaluation of CA stenosis. However, DSA is an expensive method with a neurological and non-neurological complications rate of $4 \%$ and persistent neurological deficit risk of $0.07 \%$ $0.5 \%$ (11-13). Therefore, alternative imaging methods are needed. CDUS, CTA and MRA are widely used in this regard.

CDUS is the most common and first-line method which has been used for many years in the evaluation of carotid diseases. It has advantages such as being noninvasive, inexpensive, widely available, providing functional information as well as morphological information. In addition, lack of ionising radiation is an important advantage of CDUS. However, CDUS is an operatordependent examination, and its diagnostic accuracy decreases in differentiating occlusion from severe stenosis. Due to these disadvantages of CDUS, CTA has gained increasing importance especially in patients prepared for surgery, and has been widely accepted in evaluation of the CAs, in parallel with the latest technological developments in the last decade. It has been reported that CTA was more useful than CDUS in patients considered for surgery $(14,15)$. In their study comparing CTA, CDUS and DSA, Link et al. (16) reported that CTA had higher sensitivity, specificity, and predictive values than CDUS in the evaluation of carotic disease and determining disease requiring surgery.

Saba et al. (3) investigated the correlation between stenosis grade (calculated according to the NASCET method) detected by 4-slice CTA and DUS and found a satisfactory level of correlation with the rate of $72.19 \%$ (kappa $=0.659$ ).

\begin{tabular}{|l|l|l|}
\hline \multicolumn{3}{|l|}{$\begin{array}{l}\text { Table 3. The distribution of the patients according to the mild, } \\
\text { moderate and severe stenosis determined with CDUS and CTA }\end{array}$} \\
\hline Grade of stenosis & CDUS (n, \%) & CTA (n, \%) \\
\hline Normal & $104(37.1 \%)$ & $108(38.6 \%)$ \\
\hline$<\% 50$ & $80(28.6 \%)$ & $88(31.4 \%)$ \\
\hline$\% \mathbf{5 0 - 6 9}$ & $62(22.1 \%)$ & $56(20.0 \%)$ \\
\hline$\geq \% \mathbf{7 0}$ & $34(12.2 \%)$ & $28(10.0 \%)$ \\
\hline Total & 280 & 280 \\
\hline CDUS: Color Doppler ultrasound, CTA: Computed tomographic angiography \\
\hline
\end{tabular}



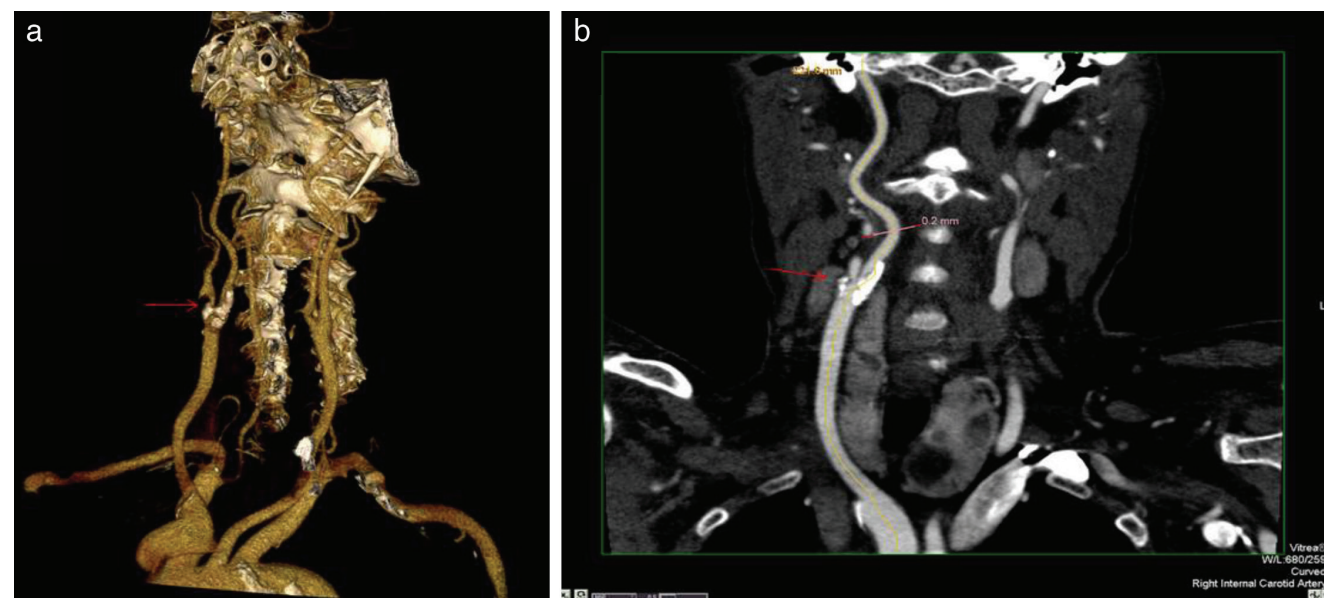

Figure 1. VR (a) CPR (b) images show $75-80 \%$ stenosis in right carotis bulb (red arrow)

VR: Volume rendering, CPR: Curved planar reformat
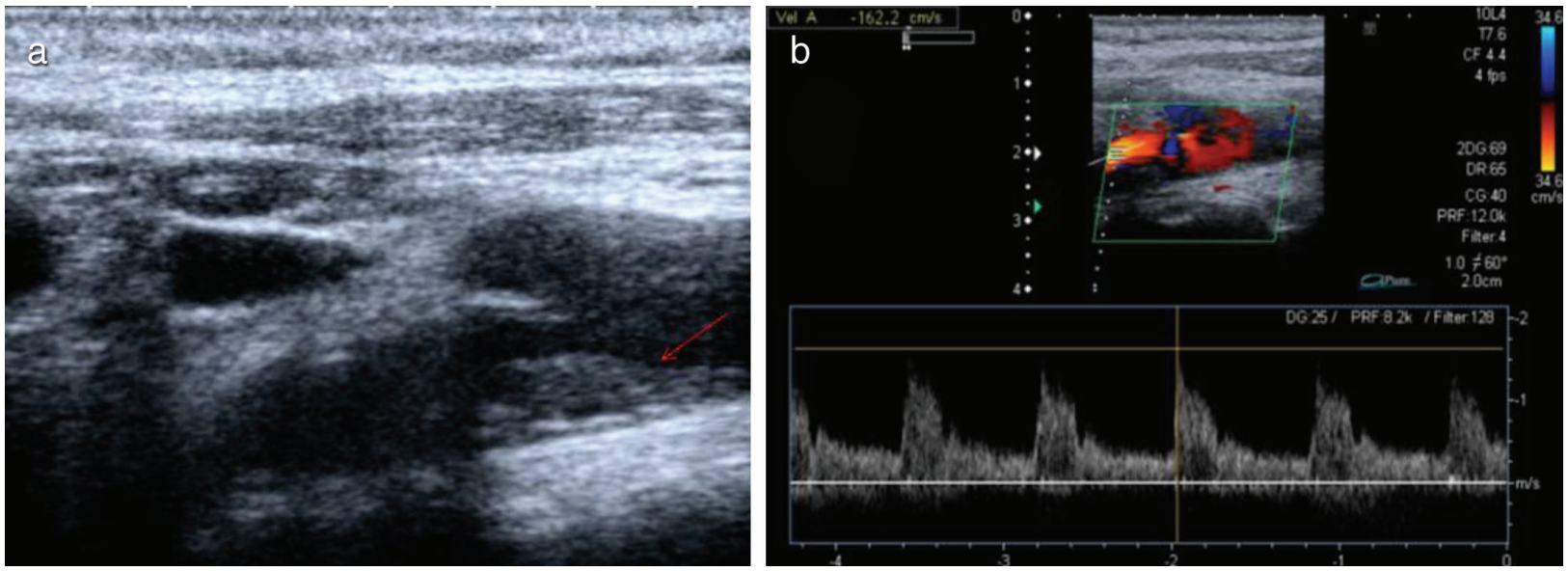

Figure 2. Longitunal image shows hypoechoic soft carotid artery bulb plaque (red arrow) (a) Spectral Doppler shows ICA stenosis of $50 \%$ to $69 \%$ diameter with a peak systolic velocity of $162 \mathrm{~cm} / \mathrm{s}$ (b)

ICA: Internal carotid artery

Prehn et al. (1) evaluated the correlation of CA stenosis determined by 16-slice CTA by using the NASCET and ECST methods with the findings of CTA and CDUS, and found a moderate correlation between the two methods.

\section{Conclusion}

In our study, the correlation between carotid stenosis grade determined by 64-slice CTA according to the CC method and stenosis grade determined by CDUS was evaluated and a high level of correlation (91\%) was detected between the two methods (correlation coefficient, $r=0.91 \quad(p<0.001)$. The reason for this high correlation, when compared to the other two studies, can be the difference in the CT technology used. We think that the increased spatial and temporal resolution in 64-slice $\mathrm{CT}$ may provide more accurate determination of stenosis grade and an opportunity to obtain results more in line with the findings of CDUS. In addition, in the aforementioned studies, stenosis degree was determined by the NASCET and ECST methods, but the CC method was used in our study; this difference may be another reason.

Although stenosis grades determined by the ECST and CC methods are compatible with each other, there are some studies reported that the NASCET method calculated stenosis grade lower than it was actually $(17,18)$. In this study, the reason for choosing the CC method in CTA for determining carotid stenosis grade is that, prospective studies with larger series have been performed with the ECST and NASCET methods, but the CC method has not been investigated widely yet $(8,19,20)$.

Staikov et al. (18) compared NASCET and ECST and CC methods for grading of carotid stenosis and they analysed 
the correlation between angiographic and DUS findings. The stenosis determined by ECST and CC was graded at a similar rate, however, NASCET underestimated stenosis degree. Reproducibility was determined by the CC method with the highest correlation, the accuracy for US with the CC and ECST methods was determined to be $94 \%$ and with the NASCET method, $84 \%$.

In their study, comparing degree of ICA stenosis measurements made by the NASCET, ECST and CC methods using 64-MDCTA, Kilıckap et al. (21) found that NASCET showed the lowest value while the degree of stenosis measured by ECST was close to that with CC. While intra and inter-observer variability of the CC method was lower than NASCET and ECST, its reproducibility was higher compared to the two other methods.

Rothwell et al. (22) demonstrated that all the three methods had similar ability of to predict ipsilateral carotid distribution ischemic stroke, but the most reproducible method was the CC.

To determine the grade of stenosis with a single method is essential for the use of a common language. For determining the standard method which will be used, the reliability of the method and the long-term results of a clinical approach determined according to stenosis grades detected by this method are essential. The indicator of the reliability of the method is the intra-observer and interobserver variability.

The CC method is a candidate for widespread use considering the studies emphasizing its higher reproducibility and less interobserver-intra-observer variability. This study indicated that stenosis measurement done with the CC method was highly correlated with DUS findings. Therefore, we consider that stenosis measurement with the CC method may be used in routine practice. Since atherosclerotic changes in CCA are less common, there is an additional advantage in taking CCA as a reference point. However, this method needs to be investigated in larger series.

\section{Authorship Contributions}

Concept: A.T., E.E., P.N.K. Design: A.T., E.E., P.N.K. Data Collection or Processing: A.T., B.K.Y. Analysis or Interpretation: A.T., B.K.Y. Literature Search: A.T., E.E. Writing: A.T., E.E.

Conflict of Interest: No conflict of interest was declared by the authors.

Financial Disclosure: The authors declared that this study received no financial support.

\section{References}

1. Prehn JV, Muhs BE, Pramanik B, et al. Multidimensional Characterization of Carotid Artery Stenosis Using CT Imaging:
A Comparison with Ultrasound Grading and Peak Flow Measurement. Eur J Vasc Endovasc Surg 2008;36:267-72.

2. Takaya N, Yuan C, Chu B, et al. Presence of intraplaque hemorrhage stimulates progression of carotid atherosclerotic plaques: a high-resolution magnetic resonance imaging study. Circulation 2005;111:2768-75.

3. Saba L, Sanfilippo R, Montisci R, Mallarini G. Agreement between multidetector-row CT angiography and ultrasound echo-color Doppler in the evaluation of carotid artery stenosis. Cerebrovasc Dis 2008;26:525-32.

4. Rothwell PM. For severe carotid stenosis found on ultrasound, further arterial evaluation prior to carotid endarterectomy is unnecessary: the argument against. Stroke 2003;34:1817-9.

5. Ross R. The Patogenesis of Atherosclerosis: A Perspective for 1990s. Nature 1993;362:801-9.

6. Anderson GB, Ashforth R, Steinke DE, Ferdinandy R, Findlay JM. CT angiography for the detection and characterization of carotid artery bifurcation disease. Stroke 2000;31:2168-74.

7. Sameshima T, Futami S, Morita $Y$, et al. Clinical usefulness of and problems with three-dimensional CT angiography for the evaluation of arteriosclerotic stenosis of the carotid artery: comparison with conventional angiography, MRA, and ultrasound sonography. Surg Neurol 1999;51:301-8.

8. Williams MA, Nicoliades AN. Predicting the normal dimensions of the internal and external carotid arteries from the diameter of the common carotid. Eur J Vasc Surg 1987;1:91-6.

9. Moneta GL, Edwards JM, Chitwood RW, et al. Correlation of NASCET: Angiographic definition. J Vasc Surg 1993;17:152-9.

10. Saba L, Caddeo G, Sanfilippo R, Montisci R, Mallarini G. CT and Ultrasound in the Study of Ulcerated Carotid Plaque Compared with Surgical Results: potentialities and Advantages of Multidetector Row CT Angiography. AJNR Am J Neuroradiol 2007;28:1061-6.

11. Hankey GJ, Warlow CP, Sellar RJ. Cerebral angiographic risk in mild cerebrovascular disease. Stroke 1990;21:209-22.

12. Waugh JR, Sacharias N. Arteriographic complications in the DSA era. Radiology 1992;182:243-6.

13. Cloft HJ, Joseph GJ, Dion JE. Risk of cerebral angiography in patients with subarachnoid hemorrhage, cerebral aneurysm, and arteriovenous malformation: a meta-analysis. Stroke 1999;30:317-20.

14. Saba L, Mallarini G. MDCTA of Carotid Plaque Degree of Stenosis: Evaluation of Interobserver Agreement. AJR Am J Roentgenol 2008;190:W41-6.

15. Saba L, Montisci R, Sanfilippo R, Mallarini G. Multidetector row $C T$ brain and carotid artery: a correlative analysis. Clinical Radyology 2009;64:767-78.

16. Link J, Brossmann J, Penselin V, Glüer C, Heller M. Common carotid artery bifurcation: preliminary results of CT angiography and color-coded duplex sonography compared 
with digital subtraction angiography. AJR Am J Roentgenol 1997;168:361-5.

17. Anderson GB, Ashforth $R$, Steinke DE, Ferdinandy R, Findlay JM. CT angiography for the detection and characterization of carotid artery bifurcation disease. Stroke 2000;31:2168-74.

18. Staikov IN, Arnold M, Mattle HP, et al. Comparison of the ECST, CC, and NASCET grading methods and ultrasound for assessing carotid stenosis. European Carotid Surgery Trial. North American Symptomatic Carotid Endarterectomy Trial. J Neurol 2000;247:681-6.

19. North American Symptomatic Carotid Endarterectomy Trial Collaborators. Beneficial effect of carotid endarterectomy insymptomatic patients high with grade stenosis. N Engl J Med 1991;325:445-53.
20. Farrel B, Fraser A, Sandercock P, Slattery J and Warlow CP. Randomised trial of endarterectomy for recently symptomatic carotid stenosis: final results of the MRC European Carotid Surgery Trial (ECST). Lancet 1998;351:1379-87.

21. Kılıckap G, Ergun Elif, Başbay E, Kosar P, Kosar U. Carotid stenosis evaluation by 64-slice CTA: comparison of NASCET, ECST and CC grading methods. Int J Cardiovasc Imaging 2012;28:1257-66.

22. Rothwell PM, Gibson RJ, Slattery J, Warlow CP. Prognostic value and reproducibility of measurements of carotid stenosis. A comparison of three methods on 1001 angiograms. European Carotid Surgery Trialists' Collaborative Group. Stroke 1994;25:2440-4. 